Pacific Northwest

National Laboratory

Operated by Battelle for the

U.S. Department of Energy

\section{Revision of the Energy-Efficiency Requirements in the Manufactured Home Construction and Safety Standards}

\author{
C.C. Conner \\ H.E. Dillon \\ R.G. Lucas \\ M Lubliner
}

June 2004

Prepared for the U.S. Department of Energy

under Contract DE-AC05-76RL01830 


\title{
DISCLAIMER
}

This report was prepared as an account of work sponsored by an agency of the United States Government. Neither the United States Government nor any agency thereof, nor Battelle Memorial Institute, nor any of their employees, makes any warranty, express or implied, or assumes any legal liability or responsibility for the accuracy, completeness, or usefulness of any information, apparatus, product, or process disclosed, or represents that its use would not infringe privately owned rights. Reference herein to any specific commercial product, process, or service by trade name, trademark, manufacturer, or otherwise does not necessarily constitute or imply its endorsement, recommendation, or favoring by the United States Government or any agency thereof, or Battelle Memorial Institute. The views and opinions of authors expressed herein do not necessarily state or reflect those of the United States Government or any agency thereof.

\author{
PACIFIC NORTHWEST NATIONAL LABORATORY \\ operated by \\ BATTELLE \\ for the \\ UNITED STATES DEPARTMENT OF ENERGY \\ under Contract DE-AC06-76RL01830
}

Ty 


\title{
Revision of the Energy-Efficiency Requirements in the Manufactured Home Construction and Safety Standards
}

\author{
C. C. Conner \\ H. E. Dillon \\ R. G. Lucas \\ M. Lubliner*
}

June 2004

Prepared for

the U.S. Department of Energy

under Contract DE-AC06-76RL01830

Pacific Northwest National Laboratory

Richland, Washington 99352

*Washington State University Energy Program

Olympia, Washington 


\begin{abstract}
Energy-efficiency requirements were developed for manufactured (mobile) homes, which are regulated by the HUD (U.S. Department of Housing and Urban Development). A life-cycle cost analysis from the homeowner's perspective was used to establish parameters for a least-cost home in a large number of cities. Economic, financial, and energy-efficiency measures for the life-cycle cost analysis were selected and documented. The resulting energy-efficiency levels were aggregated to zones that were expressed as a maximum overall home $\mathrm{U}$-value $\left(\mathrm{U}_{\mathrm{o}}\right.$, or thermal transmittance) requirement for the building envelope. The proposed revised standard's costs, benefits, and net value to the consumer were quantified. This analysis updates a similar effort completed in 1992, which was the basis for the existing HUD code $\mathrm{U}_{\mathrm{o}}$ requirement. Updated $\mathrm{U}_{\mathrm{o}} \mathrm{s}$ for manufactured homes are recommended.
\end{abstract}

This report supports a proposed change that was submitted to the National Fire Protection Association (NFPA). The submission would modify the NFPA 501 "Standard on Manufactured Housing". 


\section{Summary}

In 1987 Congress passed legislation that required the U.S. Department of Housing and Urban Development (HUD) to revise energy-efficiency standards for manufactured housing. HUD contracted with the Pacific Northwest National Laboratory (PNNL) ${ }^{\text {a }}$ to assist in developing a revision to the energyefficiency requirements in the HUD's existing Manufactured Home Construction and Safety Standards (MHCSS) (24 CFR 3280). The HUD requirements currently in effect were based on that PNNL analysis completed in 1992 (Conner et al. 1992).

More than a decade has elapsed since the analysis that resulted in the existing MHCSS. Many changes have occurred in the manufactured housing and related industries in that decade. The cost of energy-efficient window frames has been reduced, the price of low emissivity (low-E) windows has dropped dramatically, and mortgage interest rates have dropped. Vinyl windows are gaining popularity and low-E glazing is standard for some manufacturers (PATH 1999). Together these factors suggested an update to the 1992 analysis to update requirements in the MHCSS for envelope energy efficiency. ${ }^{\mathrm{b}}$ An updated analysis was conducted for the U.S. Department of Energy (DOE) to evaluate the least cost energy-efficient building envelope requirements based on current inputs. This report documents that analysis.

HUD has delegated management of the development of the MHCSS to the National Fire Protection Association (NFPA). NFPA maintains its version of the MHCSS as the Standard on Manufactured Housing, NFPA 501 (NFPA 2003). The analysis in this report supports a change proposal submitted to NFPA 501 Committee, with the expectation that the updated NFPA 501 would become the MHCSS. The energy-efficiency requirements for manufactured homes fall under the Technical Committee on Mechanical for Manufactured Housing of NFPA 501. The NFPA 501 Committee expressed an interest in a comprehensive study to evaluate the energy-efficiency requirements of the HUD code. ${ }^{c}$

Congress created the Manufactured Housing Consensus Committee (MHCC) in 2000 (PL 106-569). This HUD committee recommends changes to MHCSS in an effort to keep the MHCSS current. This committee is expected to act on reversions of NFPA 501, including any revisions resulting from this analysis, to propose updates to MHCSS.

The approach used in developing both the thermal envelope requirements in the current MHCSS and the revision proposed in this report was a cost-benefit analysis that balanced the costs of energyefficiency measures (EEM) against the benefits of energy savings. The resulting least-cost home was used to specify a minimum level of energy efficiency in terms of an overall building shell $U$-value $\left(U_{0}\right)$ that

\footnotetext{
a Operated by Battelle Memorial Institute for the U.S. Department of Energy under Contract DE-AC06-76RL0 1830.

${ }^{b}$ This building shell energy efficiency is express as a coefficient of heat transfer (Overall U-value, or $U_{0}$ ).

${ }^{c}$ In response to a proposal to modify one zone U-value requirement in NFPA 501 (Section 8.6, Coefficient of Heat Transmission), the committee stated "The proposed recommendation requires a more comprehensive study in order to evaluate the entire scope of Zone 3 and document for consistency, Zone 1 and Zone 2.” (NFPA 2002, p. 600, log \#81, proposal 501-59).
} 
resulted in the lowest total of construction and operating costs to manufactured home owners. (The $\mathrm{U}_{\mathrm{o}}$ format is used in the MHCSS.) This report documents development of the proposed revised standard.

Several major activities were required to develop the revisions proposed here. A life-cycle cost (LCC) model was required to determine the least-cost EEM investment. EEM options, including each EEM's cost and U-value, were required as input. In the 1992 analysis Congress specified a LCC analysis from the consumer's perspective as the basis for revising the HUD thermal standard. The same perspective is used here for the updated analysis. A life-cycle cost analysis compares the total long-run (present value) costs for several alternative courses of action and selects the option with the least cost. For this LCC analysis the economic benefit is the energy savings from the EEMs; the major cost is the EEM cost, including the associated mortgages, fees, and payments. The calculation required definition of the financial, economic, and fuel price parameters used in the life-cycle cost analysis. Initially, separate $\mathrm{U}_{\mathrm{o}} \mathrm{s}$ were defined for a large number of U.S. cities for homes with different heating fuel/equipment types. These separate $\mathrm{U}_{\mathrm{o}} \mathrm{s}$ were aggregated into large geographical zones in which a specific U-value requirement applies.

The analysis to develop both the 1992 standard and the proposed revised standard was done with the Automated Residential Energy Standard (ARES) software. DOE developed ARES as a tool for creating residential energy-efficiency standards. The ARES implements an LCC methodology for residential energy-efficiency decisions. ARES incorporates an energy simulation-based database, thereby allowing ARES to project energy costs for a range of alternative EEMs. Given a set of fuel price, financial, economic, and EEM costs for a building at a specific location, ARES identifies the set of EEMs to invest in, such that the homeowner's total life-cycle cost is minimized.

Several financial, economic, and fuel price parameters were required for the LCC analysis. The legislative requirements on 1992 analysis included that the costs and benefits be calculated from the home owner's perspective, and that the physical lifetime of the structure be used as the analysis period. These requirements were carried into this revised LCC analysis. Because most homes are purchased with financing, the development of the proposed requirements accounts for financing. A loan with a $10 \%$ mortgage rate over 15 years with a down payment of $10 \%$ was assumed. The nominal discount rate was $10 \%$ (about $8 \%$ real). The inflation rate was $2.3 \%$. The period of analysis and building lifetime were both set to 30 years. Each state's average residential fuel prices were defined for electricity, fuel oil, natural gas, and liquid petroleum gas (LPG). Residential fuel price escalation rates were defined. The annual fuel escalation rates (real) were: electricity, $-0.2 \%$; fuel oil, $0.4 \%$; natural gas, $0.4 \%$; and LPG, $0.5 \%$.

The EEMs selected represent the choices used in a life-cycle cost analysis to determine the consumer's least-cost investment in energy conservation. For each type of EEM (e.g., wall insulation), lists of candidate options, costs, and thermal characteristics were developed.

Only EEMs determined to be available in commercially produced homes were included as candidate options. The range of insulation levels included as options are shown in Table S.1. 
Table S.1 Range of Energy-Efficiency Options

\begin{tabular}{lc} 
Building Component & Range of Options \\
\hline Ceiling & R-11 to R-38 \\
Wall & R-11 to R-21 \\
Floor & R-11 to R-33 \\
Windows & U-1.2 to U-0.35
\end{tabular}

Heating and cooling equipment efficiencies are required for life-cycle cost analysis. The National Appliance Energy Conservation Act 1987 (NAECA) minimum standards for heating and cooling system efficiency in manufactured homes were assumed.

Initially, calculations were done for single- and double-wide homes with five different equipment/fuel types. Results for single-wide homes were similar to the results for double-wide homes so only the more common double-wide was used. The five equipment/fuel types were:

- natural gas with a forced air furnace

- LPG with a forced air furnace

- oil with a forced air furnace

- electric resistance with a forced air furnace

- electric heat pump with forced air distribution.

In all cases an electric air-conditioning system was included.

Rather than selecting a few cities to represent the U.S, all 881 cities available in ARES were used. Selection of all 881 cities provided a density of locations such that any point in the U.S. was close to a city for which a least-cost $\mathrm{U}_{\mathrm{o}}$ was produced. This coverage helped avoid bias that might result from selecting a small number of cities to encompass a large area of the country.

After the production of the $4,405 \mathrm{U}_{\mathrm{o}} \mathrm{s}$ (881 cities for five HVAC/fuel types), the individual U-values were aggregated to form geographical zones.

- Individual city $\mathrm{U}_{\mathrm{o}} \mathrm{s}$ were aggregated into $\mathrm{U}$-values by HVAC type and fuel type for each state.

- $\mathrm{U}_{0} \mathrm{~s}$ for the separate HVAC equipment and fuel types were aggregated together in each state.

- Maximum $\mathrm{U}_{\mathrm{o}}$ for each zone was defined by the sales in weighted average of the $\mathrm{U}_{\mathrm{o}} \mathrm{s}$ in each state.

The zones and resulting $\mathrm{U}_{\mathrm{o}}$ for each zone shown in Figure S.1 and Table S.2.

The updated standard proposed here was compared to 1992 standard. The comparison between the standards was done in terms of a national average $U_{0}$ for each standard as tabulated in Table S.3. The revised $\mathrm{U}_{\mathrm{o}}$ s proposed here is more energy efficient than the 1992 standard. 


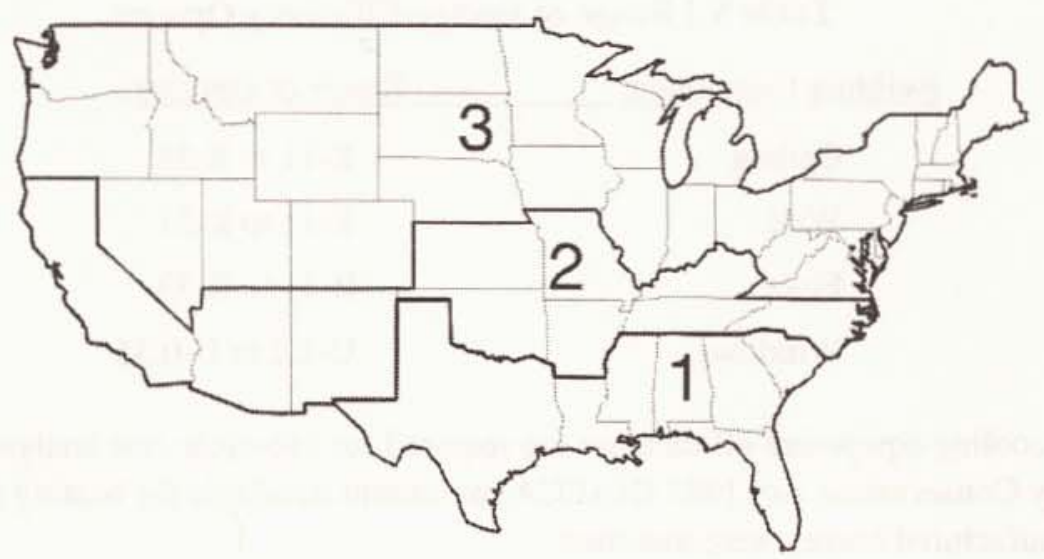

Figure S.1 Existing $U_{0}$ Zones

Table S.2 Zone $\mathrm{U}_{\mathrm{o}}$

\begin{tabular}{|c|c|c|}
\hline Zone & Existing $\mathrm{U}_{\mathrm{o}}$ & Revised $\mathrm{U}_{\mathrm{o}}$ \\
\hline 1 & 0.116 & 0.086 \\
\hline 2 & 0.096 & 0.076 \\
\hline 3 & 0.079 & 0.064 \\
\hline
\end{tabular}

Table S.3 Average National $\mathrm{U}_{\mathrm{o}} \underline{\text { Average }_{\mathrm{U}}}$

0.097

0.075

\section{Standard}

Existing standard

Proposed revised $\mathrm{U}_{0}$

The proposed standard also has a number of positive social impacts including a reduction in the environmental impacts resulting from decreased energy use. These benefits include reduced peak utility loads, improved national balance of payment, and improved energy security. The value of these benefits was not estimated and is not accounted for in the LCC analysis.

Based on the contents of this report, revised $\mathrm{U}_{\mathrm{o}}$ requirements in NFPA 501 and MHCSS were recommended. The committee ultimately revised the Uo, but not to the full degree suggested by this report. 


\section{Contents}

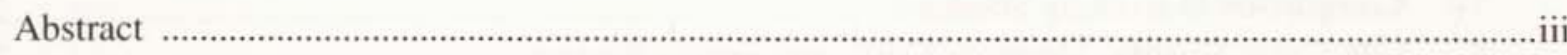

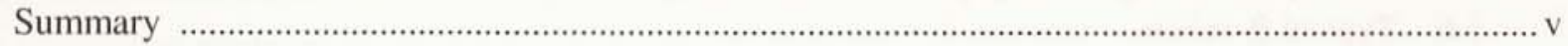

$1.0 \quad$ Introduction

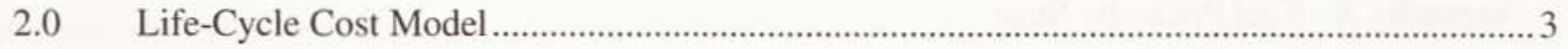

2.1 Legislative Requirements Pertaining to Least-Cost Analysis .................................................... 3

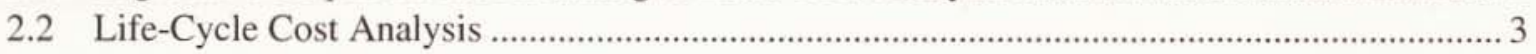

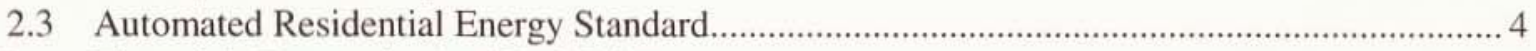

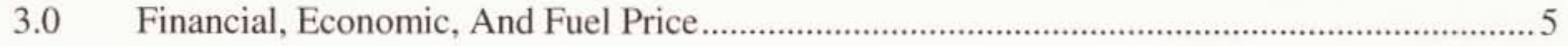

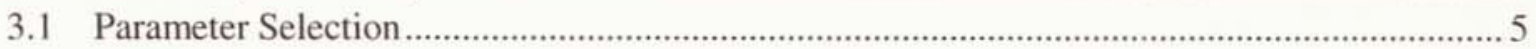

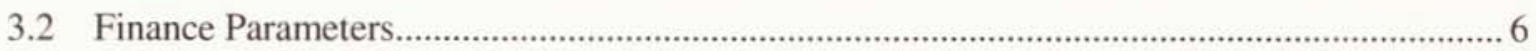

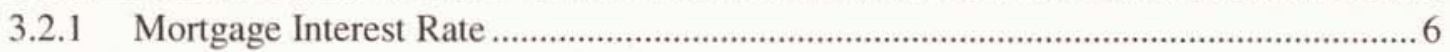

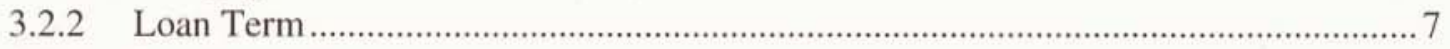

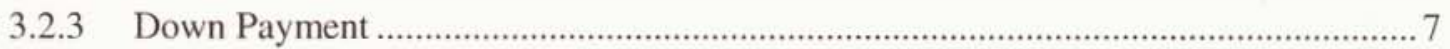

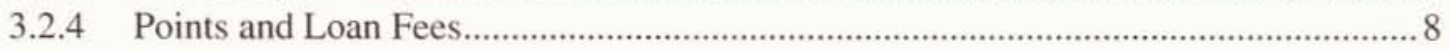

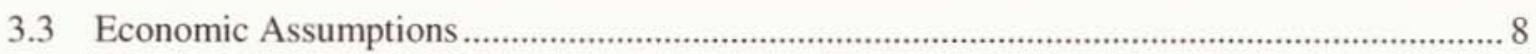

3.3.1 Discount Rate (Alternative Investment Rate) ............................................................ 8

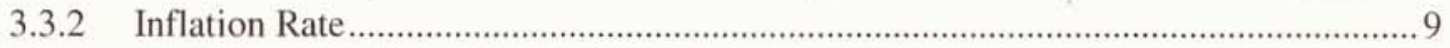

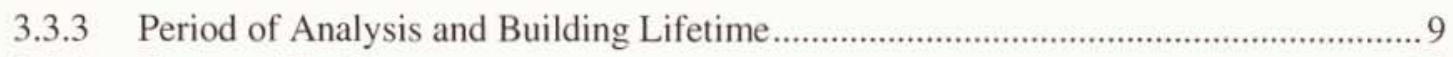

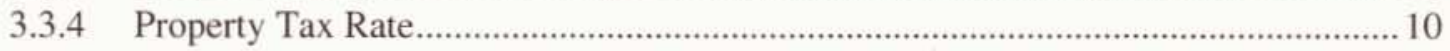

3.3.5 Income Tax Rate ................................................................................................. 10

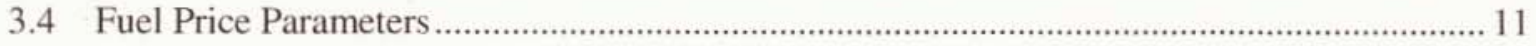

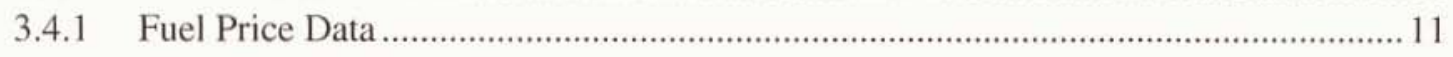

3.4.2 Fuel Price Escalation Rates ..................................................................................... 11

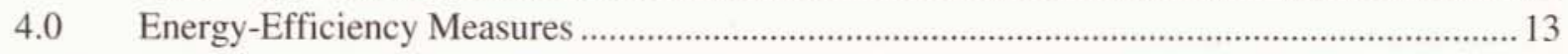

4.1 Legislative Requirements for Energy-Efficiency Measure Selection .................................... 13

4.2 Energy-Efficiency Measure Characteristics Required .......................................................... 13

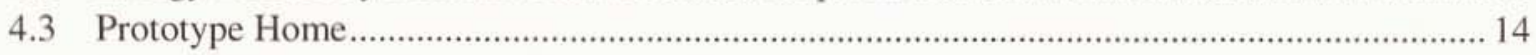

4.4 Energy-Efficiency Measure Cost and Characteristics ............................................................. 15

4.4.1 Energy-Efficiency Measure Cost Determination ...................................................... 15

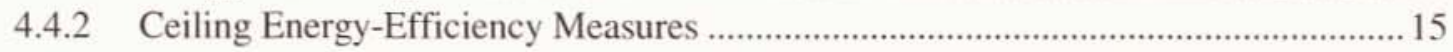

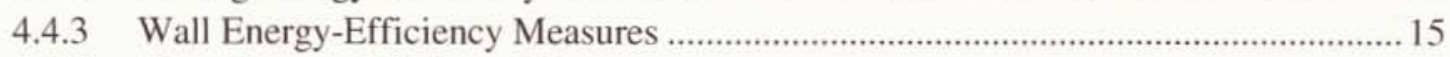

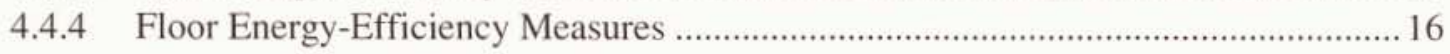

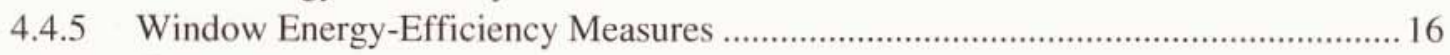

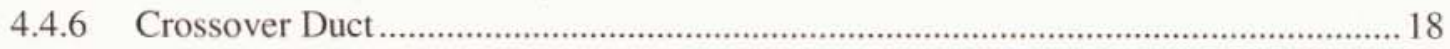

4.4.7 Door Energy-Efficiency Measures ............................................................................... 18

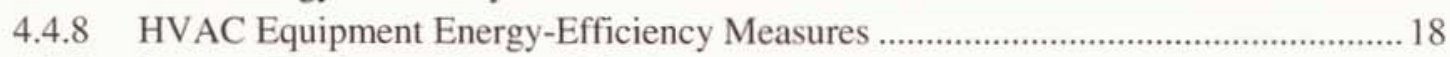

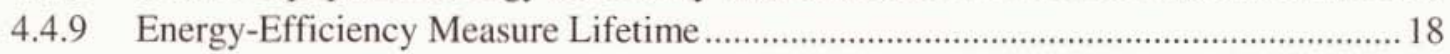

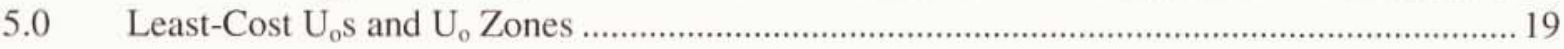




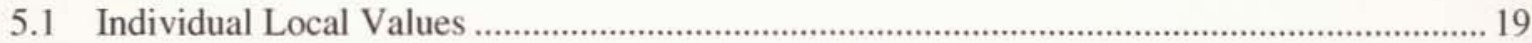

5.2 Aggregation Across Equipment and Fuel Types .................................................................... 21

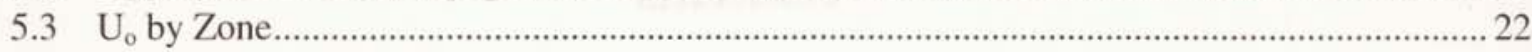

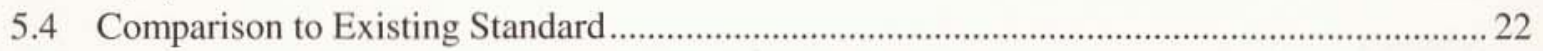

5.5 Life-Cycle Savings, Mortgage Costs, and Energy Savings ….................................................. 22

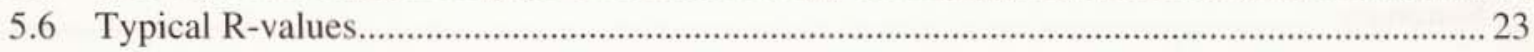

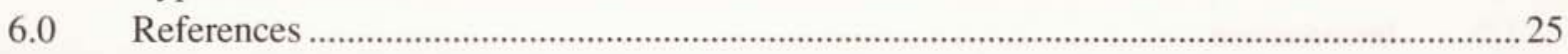

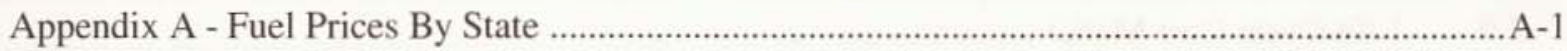

Appendix B - Home Shipments By State ……............................................................................. B-1 


\section{Figures}

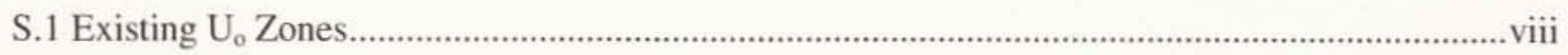

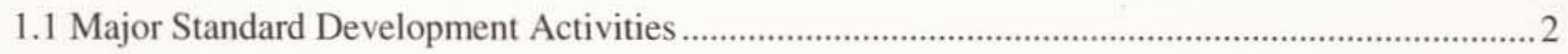

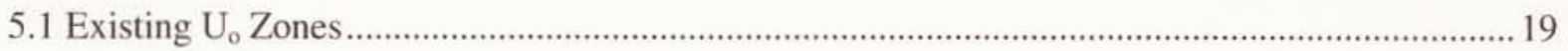

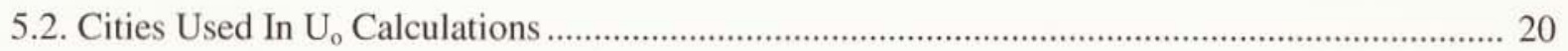




\section{Tables}

S.1 Range of Energy-Efficiency Options …....................................................................................... vii

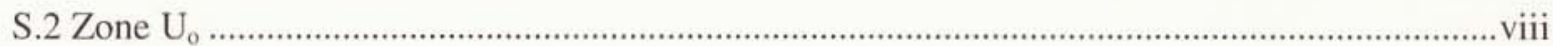

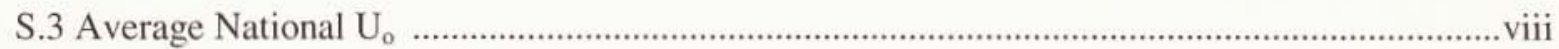

3.1 Financial, Economic and Fuel Price Assumptions ....................................................................... 5

3.2 Indirect Financing of Manufactured Homes........................................................................... 6

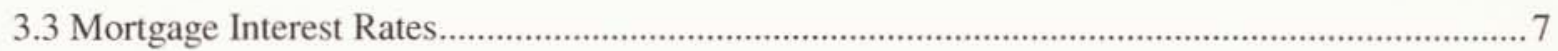

3.4 Reported Loan Terms for Manufactured Homes........................................................................... 7

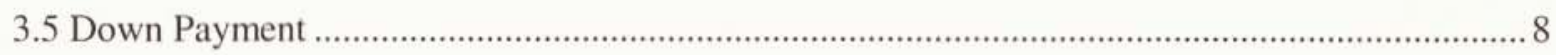

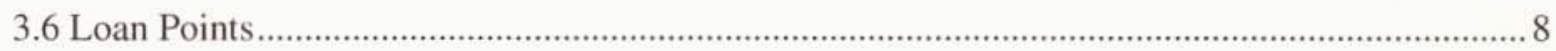

3.7 Estimated Lifetime for Manufactured Homes ................................................................................ 9

3.8 Estimated Property Tax Rates for Manufactured Homes ............................................................... 10

3.9 Projected Fuel Price Escalation Rate........................................................................................... 11

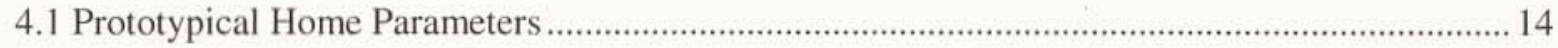

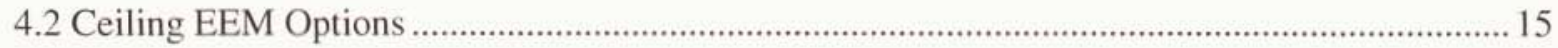

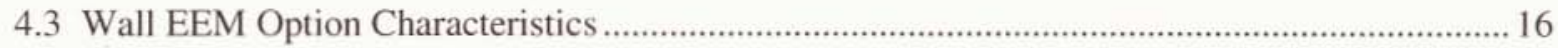

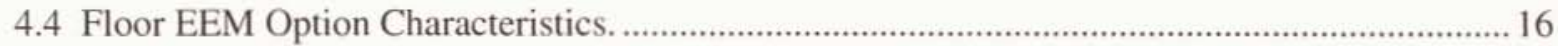

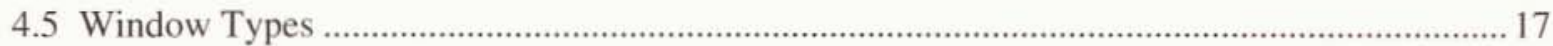

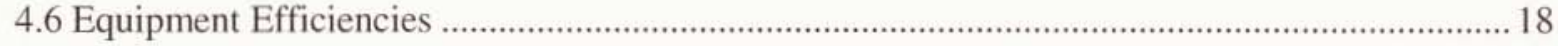

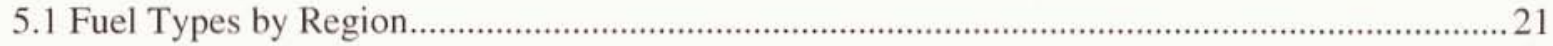

$5.2 \mathrm{U}_{\mathrm{o}}$ by Zone

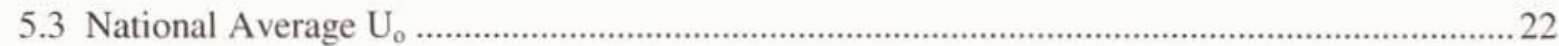

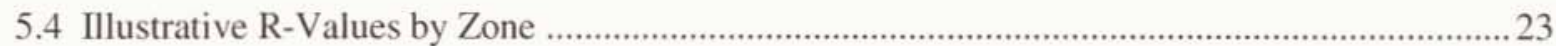

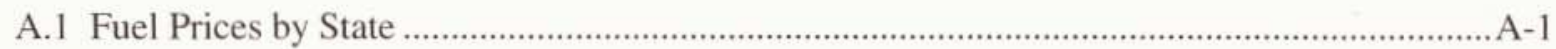

B.1 2001 Home Shipments by State ................................................................................................. 


\subsection{Introduction}

Congress passed the Housing and Community Development Act of 1987 requiring the U.S. Department of Housing and Urban Development (HUD) to revise energy-efficiency standards for manufactured housing (HCDA 1987; CRH 1987; CRS 1987). The HUD contracted with the Pacific Northwest National Laboratory (PNNL) a to perform the analysis, which led to the existing energyefficiency requirements in HUD's Manufactured Home Construction and Safety Standards (MHCSS) (24 CFR 3280). The past work is documented in a separate report (Conner et al. 1992). The DOE ${ }^{b}$ sponsored the current work to update the 1992 analysis. This new analysis supports a proposed revision to National Fire Protection Agency (NFPA) 501 Standard on Manufactured Housing. The NFPA 501 Committee maintains the development process for HUD's MHCSS.

The approach used in developing the proposed revised standards was a cost-benefit analysis in which the costs of energy-efficiency measures (EEMs) were balanced against the benefits of energy savings. The resulting recommendation specified an overall level of energy conservation in terms of a building shell $\mathrm{U}_{\mathrm{o}}$-value (thermal transmittance) that gave the lowest total of construction and operating costs to the owner of a manufactured home. This life-cycle cost calculation was performed for a large number of cities in the U.S. The resulting $\mathrm{U}_{0} \mathrm{~s}$ were grouped into zones with county or state boundaries, with each zone having a specific $\mathrm{U}_{\mathrm{o}}$ requirement. This report documents the development of the revised standard.

Major activities in the development of the revised standard are illustrated in Figure 1.1. Chapters of this report are organized as follows. Chapter 2 presents a brief overview of the life-cycle cost model. Chapter 3 discusses the choice of the financial, economic, and fuel price parameters used in the life-cycle cost analysis. Chapter 4 describes the energy-efficiency measures and their characteristics. Chapter 5 describes the creation of the $\mathrm{U}_{\mathrm{o}} \mathrm{s}$ for specific cities with various fuel types and HVAC (heating, ventilation and air-conditioning) equipment. Chapter 5 also describes aggregation of the individual $\mathrm{U}_{\mathrm{o}} \mathrm{s}$ into the $\mathrm{U}_{\mathrm{o}}$ zones and compares the $\mathrm{U}_{\mathrm{o}} \mathrm{s}$ from this proposed revision to the existing $\mathrm{U}$-values.

This report refers to the existing overall $\mathrm{U}$-value $\left(\mathrm{U}_{\mathrm{o}}\right)$ and zones in the MHCSS and also in NFPA 501 as the "1992" standard. The new $\mathrm{U}_{0}$ requirements proposed herein are referred to as the "revised". standard.

(a) Operated by Battelle Memorial Institute for the U.S. Department of Energy under Contract DE-AC06-76RL0 1830.

(b) The DOE project manager was Chris Early, Office of Energy Efficiency and Renewable Energy, Building Technology Program. 


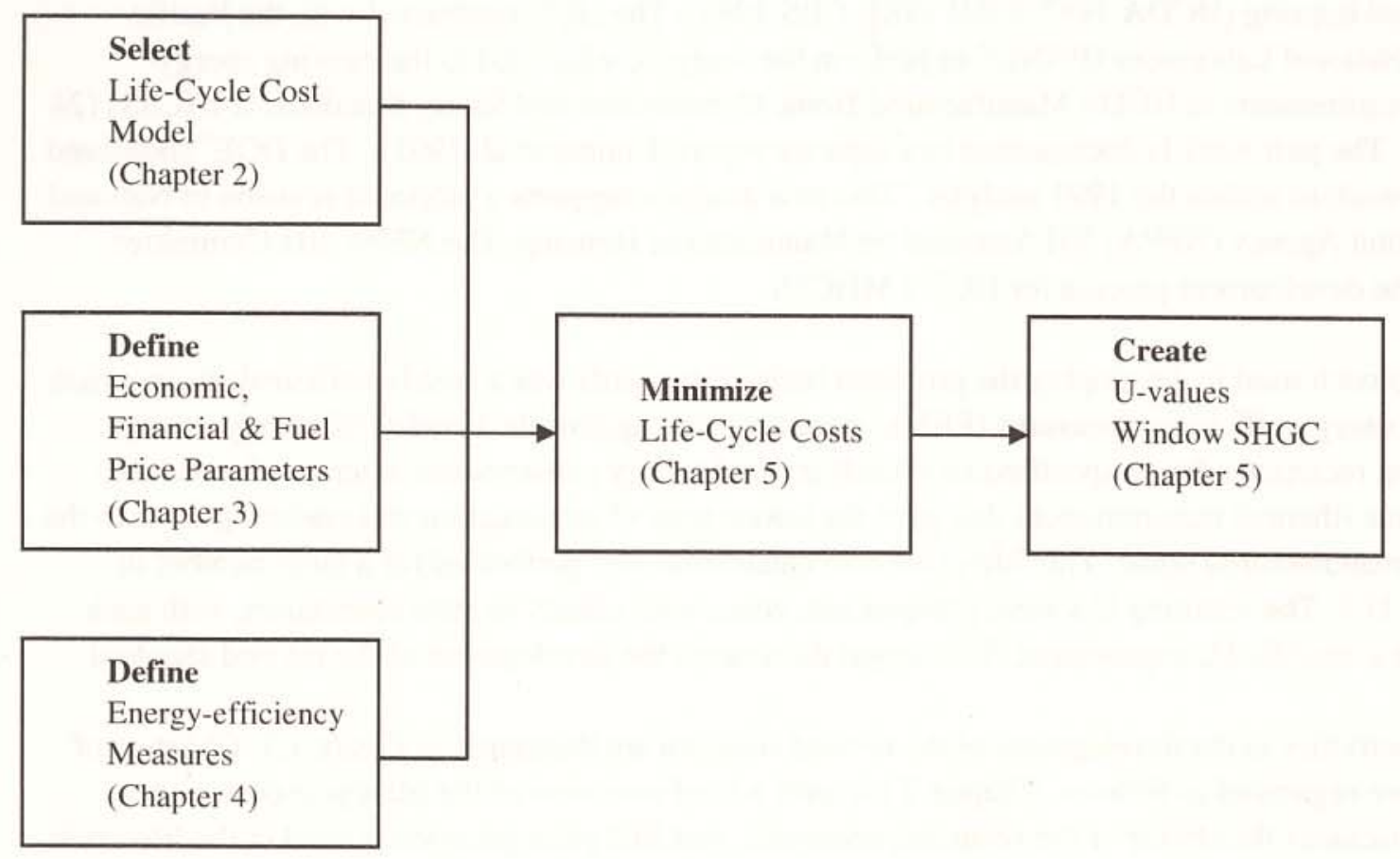

Figure 1.1 Major Standard Development Activities 


\subsection{Life-Cycle Cost Model}

This chapter describes the selection of the life-cycle cost (LCC) model used to generate the proposed revision of the HUD/NFPA standard. Section 2.1 describes the legislative requirements for the 1992 standard as they relate to selection of the LCC model. Section 2.2 describes a generic life-cycle cost analysis. Section 2.3 briefly describes the model selected.

\subsection{Legislative Requirements Pertaining to Least-Cost Analysis}

The Housing and Community Development Act of 1987 and the accompanying conference reports (HCDA 1987, CRH 1987, CRS 1987) used in the original analysis defined the type of calculation to be used to set the existing HUD standard. The methodology was to be chosen to "ensure the lowest total of construction and operating costs." (HCDA 1987). The methodology was required to "result in the lowest possible total cost taking into consideration down payment, financing, construction, and energy costs" (CRH 1987). The method was specified to be "a life cycle cost analysis" (CRS 1987).

\subsection{Life-Cycle Cost Analysis}

Life-cycle cost methods are used to compare the total long-run (present value) costs of several alternative courses of action to achieve an objective. The course of action with the least cost is typically the preferred alternative. LCC analysis sums the (discounted) costs and benefits of the investment, which, in turn, are calculated based on existing and forecasted economic parameters. For the analysis to be credible, the parameters used in the analysis must reflect present or expected market conditions. The elements of a LCC analysis are shown below. All costs and benefits are computed in present value dollars.

Life-cycle cost $=$ Investment + Operating costs + Maintenance costs - Resale value

The first element represents the initial investment outlay. For this analysis, the initial investment is the purchase and financing of manufactured home EEMs. The second element is the cost of operating the building, the cost of the energy required to keep the building comfortable. A reduction in the energy costs is the benefit of the standard in this analysis. The third element represents the operation and maintenance outlays required to maintain the investment following its purchase. For the standard, this represents the maintenance, repair, or replacement required for the EEMs. The final element represents the resale value of the investment after it has reached the end of its expected useful life. 


\subsection{Automated Residential Energy Standard}

The analysis tool used to develop both the existing and the revised standard was the Automated Residential Energy Standard (ARES) program. The ARES software is a computer program developed for the U.S. Department of Energy (DOE). ${ }^{a}$ The ARES implements an LCC methodology for residential energy-efficiency decisions. Given a set of fuel price, financial, economic, and EEM costs for a building at a specific location, ARES identifies the set of EEMs to invest in, such that the homeowner's total lifecycle cost is minimized. ARES was designed specifically for development of residential energyefficiency standards.

Besides a life-cycle cost model, ARES incorporates an energy estimation tool allowing it to project energy use for a residence. The energy usage for each EEM becomes an input to the ARES life-cycle cost analysis. The incorporation of an energy simulation in ARES removes the requirement for doing separate building energy simulations. ARES energy analysis includes a parameterization of a large data base of DOE-2 simulations and, therefore, the energy savings projected by ARES are based on the U.S. Department of Energy's DOE-2 simulation program.

(a) This document focuses on the work unique to the development of the proposed revision of the NFPA 501. ARES is documented in Lortz and Taylor (1989). 


\subsection{Financial, Economic, and Fuel Price}

The financial, economic and fuel price assumptions to develop the least-cost manufactured home are specified, justified, and documented in this chapter. Table 3.1 below summarizes these assumptions.

Table 3.1 Financial, Economic and Fuel Price Assumptions

\begin{tabular}{|l|c|}
\hline \multicolumn{2}{|c|}{ Finance parameters } \\
\hline Mortgage interest rates & $10 \%$ \\
\hline Loan term & 15 years \\
\hline Down payment & $10 \%$ \\
\hline Loan fees and points & $1 \%$ \\
\hline \multicolumn{2}{|c|}{ Other rates and times } \\
\hline Discount rate (nominal) & $10 \%$ \\
\hline Inflation rate & $2.3 \%$ \\
\hline Period of analysis & 30 years \\
\hline Building lifetime & 30 years \\
\hline Property tax rate & $1 \%$ \\
\hline \multicolumn{2}{|c|}{ Fuel prices by state } \\
\hline See values in Appendix A & \\
\hline \multicolumn{2}{|c|}{ Fuel price escalation rates (real) } \\
\hline Electricity & $-0.2 \%$ \\
\hline Fuel oil & $0.4 \%$ \\
\hline Natural gas & $0.4 \%$ \\
\hline Liquid petroleum gas & $0.5 \%$ \\
\hline
\end{tabular}

\subsection{Parameter Selection}

In choosing the assumptions for the analysis, the intent was to identify the best source for the parameter. Most of the values are commonly reported statistics, traceable to published sources. It should be noted that some values vary across time, location, markets, institutions, circumstances, and individuals. If multiple sources for a parameter were identified, an attempt was made to choose the best source, with a bias towards the most recent and best documented sources. Various parameters were set for the 1992 analysis (Conner et al. 1992) by the Housing and Community Development Act of 1987 and the accompanying conference reports (HCDA 1987, CRH 1987, CRS 1987). The original financial, economic, and fuel price selection criteria remain valid for the current work and were used for the revised standard. 


\subsection{Finance Parameters}

The majority of manufactured homes purchased are financed. For example, Bankrate.com (2003) states that $90 \%$ of the new manufactured homes are financed. Because most new manufactured homes are financed, the life-cycle cost analysis presumed the home was financed. Several financing parameters affecting the cost and duration of the loan were defined. These parameters are the mortgage interest rate, loan term, down payment, points, and loan fees. Table 3.1 shows the parameters selected for this analysis.

\subsubsection{Mortgage Interest Rate}

A mortgage interest rate of $10 \%$ was selected for this analysis, based on the long-term average rates and a blended direct and indirect mortgage rate.

Manufactured homes may be financed directly (financed through a lending institution) or indirectly (financed through the home dealership). Recent sources reporting indirect and direct financing percentages are shown in Table 3.2.

Table 3.2 Indirect Financing of Manufactured Homes

\begin{tabular}{|c|c|}
\hline Indirectly Financed & Source \\
\hline $75 \%$ & PATH 2000 \\
\hline $78 \%$ & NAHBRC 1998 \\
\hline $82.6 \%$ & Conwell 1999 \\
\hline $86.7 \%$ & Conner et al. 1992 \\
\hline
\end{tabular}

Interest rates for directly financed loans reported by several sources are summarized in Table 3.3. Rates for indirect financing are reported as percentage points above traditional mortgage rates.

The American Housing Survey (US Census 2001) reports that long-term historical average for direct loans for site-built homes is near $8 \%$. Freddie Mac reports that the average for last 10 years is near $7.5 \%$. Similar rates would apply to "land and home" financing, where a manufactured home is sold with land and installed on a permanent foundation.

The interest rate for indirect financing is reported in Table 3.3 to be $1.5 \%$ to $4 \%$ higher than the interest rate direct financing. About $75 \%$ to $80 \%$ of the homes are financed indirectly. Based on these sources, an interest rate of $10 \%$ was assumed. 
Table 3.3 Mortgage Interest Rates

\begin{tabular}{|c|c|c|}
\hline Mortgage Rates & Description & Source \\
\hline $3-4 \%$ higher & Higher than direct & PATH 2000 \\
\hline $2-3 \%$ higher & Higher than direct & MHI 2003b \\
\hline 1.5 to 3\% higher & Higher than direct & Levy 1989 \\
\hline $8.06 \%$ & Average site-built home rate & NAHB 2000 \\
\hline $7.5 \%$ & Average direct rate & Freddie Mac \\
\hline $1.1 \%$ higher & Higher than site-built & AHS 2001 \\
\hline $14 \%$ & For manufactured homes & Levy 1989 \\
\hline $14 \%$ & For manufactured homes & Conner et al. 1992 \\
\hline
\end{tabular}

The assumed interest rate is not intended to represent the current near-record low rates, but to represent a long-term interest rates on manufactured homes. The selected interest rate is based on the historical long-term interest rate for traditional financing and an assumed increase for indirectly financed homes. There is a trend towards lower cost financing and multi-section homes. Over time, these trends will lower the least-cost $\mathrm{U}_{\mathrm{o}}$.

\subsubsection{Loan Term}

The current analysis used a loan term of 15 years, which was selected as representative of the range of available estimates. The average loan term was estimated by several sources with a range of 13 to 30 years as shown in Table 3.4. The 15-year term is consistent with the American Housing Survey (US Census 2001) median for all manufactured homes and close to the loan term used in the previous analysis.

Table 3.4 Reported Loan Terms for Manufactured Homes (years)

\begin{tabular}{|c|l|c|}
\hline Loan Term & \multicolumn{1}{c|}{ Description } & Source \\
\hline 18 & Median for manufactured homes & AHS 2001 \\
\hline 13 and 16 & Single- and multi-section homes & NAHBRC 1998 \\
\hline $25-30$ & Typical home financing term & MHI 2000 \\
\hline 15 & Typical home financing term & PATH 2000 \\
\hline 15 & Term for LCC analysis & Levy 1989 \\
\hline 14 & From the 1988 Foremost Survey & Conner et al. 1992 \\
\hline
\end{tabular}

\subsubsection{Down Payment}

Most of the literature surveyed reported (or assumed) a down payment amount of approximately $10 \%$ as typical, as shown in Table 3.5. A down payment of $10 \%$ was used for the analysis. 
Table 3.5 Down Payment

\begin{tabular}{|c|c|}
\hline $\begin{array}{c}\text { Down Payment } \\
\text { (percent of sale price) }\end{array}$ & Source \\
\hline $10 \%$ & NAHBRC 1998 \\
\hline 5 to $10 \%$ & MHI 2000 \\
\hline $10 \%$ & PATH 2000 \\
\hline $10 \%$ & Levy 1989 \\
\hline $15 \%$ & Conner et al. 1992 \\
\hline
\end{tabular}

\subsubsection{Points and Loan Fees}

There is little information about the average number of loan points used to finance a typical manufactured home. Values chosen for other cost analysis work are shown in Table 3.6. The value used by NAHB seemed unreasonably high, particularly when combined with the higher manufactured home interest rates. The value of $1 \%$ of the mortgage was retained from the 1992 work for this analysis.

Table 3.6 Loan Points

\begin{tabular}{|c|c|}
\hline Points & Source \\
\hline $5 \%$ & NAHBRC 1998 \\
\hline $1 \%$ & Levy 1989 \\
\hline $1 \%$ & Conner et al. 1992 \\
\hline
\end{tabular}

\subsection{Economic Assumptions}

For this analysis a discount rate, inflation rate, and period of analysis need to be established.

\subsubsection{Discount Rate (Alternative Investment Rate)}

A life cycle cost minimization must sum costs and benefits occurring in different years into a common valuation. To sum costs and benefits occurring in future years as a present value, a discount rate needs to be established. The establishment of the discount rate for energy-efficiency analysis is often a contentious issue. Six possible methods of determining discount rates are discussed in detail by the 1992 analysis documentation (Conner et al. 1992).

Mortgage prepayment is an "investment" available to consumers who purchase manufactured homes using financing. An argument for using a discount rate established by mortgage prepayment is that the home buyer has borrowed money at that rate, demonstrating that his implicit discount rate must be at least that high. Further, paying off the mortgage early represents a reasonable and usually available alternative 
investment for the consumer. Mortgage prepayment was used to establish the discount rate in the 1992 standard and retained for this analysis; therefore, a nominal discount rate of $10 \%$ (equal to the mortgage interest rate) was used in this analysis.

\subsubsection{Inflation Rate}

The inflation rate is used to convert between nominal and real rates used in this analysis. The nominal rates (rates that include inflation) are the mortgage and discount rates. The fuel escalation rates, described later in this section are real rates. The Council of Economic Advisors (2002) provides a long-term prediction of the inflation rate, $2.3 \%$ annually, which was chosen for this analysis.

\subsubsection{Period of Analysis and Building Lifetime}

The analysis that led to the 1992 standard was governed by guidelines in legislation. One requirement was that the analysis period as the "effective physical life of the structure" (CRS 1987). Other works have challenged the assumption of a longer period of analysis, noting that homeowner's average time in their new home is much shorter that the home's lifetime. Levy assumed an analysis period of only 7 years, or the approximate time that the first homebuyer might live in the home (Levy 1989). Because the analysis reported here is intended to represent the interests of all the consumers who live in the house and energyefficiency features last much longer than the average occupant, a longer analysis period was used. Some indications of resale value support the assumption that the homebuyer recoups much of the investment on resale. ${ }^{\mathrm{a}}$ A high resale value makes the assumed period of analysis less important. The longer analysis is consistent with the methodology used to determine the existing MHCSS.

The average useful life for new manufactured homes that are continuously occupied is estimated by several sources as shown in Table 3.7. A conservative 30-year lifetime was selected for this work. The impacts of the selection of a lifetime is significantly moderated by the effect of the discount rate in reducing the value of costs and benefits that far into the future.

Table 3.7 Estimated Lifetime for Manufactured Homes (years)

\begin{tabular}{|c|c|}
\hline Building Lifetime & Source \\
\hline 57.5 & Meeks 1998 \\
\hline 33.4 & Gates 1986 \\
\hline 45 & Eckman 2002 \\
\hline
\end{tabular}

\footnotetext{
a For example: NADA's Manufactured Housing Appraisal Guide (NADA 2003, Jan-April 2003, Part 3, Page 31) double section Super Good Cents/Natural Choice home with R19 walls, R33 floor, R38 ceiling, and R5 doors with vinyl frames and low-E glass have an additional resale value of $\$ 1990$ after year five and beyond. Although not stated, the "base" home would presumably be a home built to the MHCSS minimum requirements.
} 


\subsubsection{Property Tax Rate}

Property taxes vary widely from state to state and within a particular state. The 1992 analysis assumed a property tax rate of $2 \%$. It could be argued that the process that sets the property tax assessments is not sophisticated enough to recognize energy efficiency such as higher insulation values; therefore, energy efficiency would not affect the property tax. The median income tax rate reported by the American Housing Survey (US Census Bureau 2001) for all manufactured homes is 1\%. For this analysis, a property tax rate of $1 \%$ was assumed.

Many owners of manufactured homes do not pay property taxes because such homes are classified as personal property rather than real property. These homeowners will often pay personal property taxes that are estimated to be approximately equivalent. Estimated tax rates are shown in Table 3.8.

Table 3.8 Estimated Property Tax Rates for Manufactured Homes

\begin{tabular}{|c|c|}
\hline Tax Rate & Source \\
\hline $1 \%$ & US Census Bureau $2001^{\mathrm{a}}$ \\
\hline $2 \%$ & Levy 1989 \\
\hline $2 \%$ & Conner et al. 1992 \\
\hline
\end{tabular}

\subsubsection{Income Tax Rate}

The marginal income tax rate paid by the homeowner determines the value of the mortgage tax deduction. However, most owners of the manufactured homes do not itemize their income tax deduction. The Internal Revenue Service (IRS) (1999) reported that $31.7 \%$ of tax filers itemized on their tax returns (IRS 1999). Foremost (2002) reports that $83 \%$ of manufactured home owners made less than $\$ 50,000$ per year. Of those tax filers that made less than $\$ 50,000$ per year, only $11.4 \%$ itemized. Based on these statistics, it is assumed that only a small portion of manufactured home owners itemized their income tax; therefore, no benefit to the homeowner was assumed for the mortgage tax deduction.

\footnotetext{
a The value from the American Housing Survey (2001) was calculated from the median reported \$9 per $\$ 1000$ value.
} 


\subsection{Fuel Price Parameters}

Both current fuel prices and fuel price escalation rates were required for this analysis.

\subsubsection{Fuel Price Data}

The average residential fuel price used in each state for electricity, distillate fuel oil, liquid petroleum gas (LPG) and natural gas is shown in Appendix A. Residential fuel prices are taken from the Energy Information Agency (2003a, 2003b, 2003c). The summer (air conditioning) and winter (heating) variation in electricity rates was accounted for.

\subsubsection{Fuel Price Escalation Rates}

The residential fuel price escalation rates (real) were reported by Fuller and Boyles (2003). The escalation rates are projected for 25 years for the residential sector by fuel type.

Table 3.9 Projected Fuel Price Escalation Rate (\%)

\begin{tabular}{|c|c|c|c|}
\hline Electricity & Fuel Oil & Natural Gas & LPG \\
\hline-0.2 & 0.4 & 0.4 & 0.5 \\
\hline
\end{tabular}




\subsection{Energy-Efficiency Measures}

The analysis used to develop the revised overall U-values and zones for manufactured housing requires information on specific EEMs. This analysis determines the homeowner's least-cost investment in energy efficiency by minimizing the sum of the costs and benefits, including both EEM purchase and energy costs. The EEMs options are considered as alternative construction options that can be compared to determine the least-cost package of options that, in turn, provides the basis for the standard.

This chapter primarily documents the characterization of the EEM options used in the life-cycle cost analysis. Section 4.1 summarizes the legislative requirements related to EEMs that were used to frame the analysis for the revised requirements. Section 4.2 lists the EEM information required by this analysis. Section 4.3 discusses the prototype homes selected for the analysis. Section 4.4 presents the analysis of EEM costs and characteristics data, including selection of EEMs and determination of costs for insulation in ceilings, walls, and floors; and determination of the types and costs of the windows.

\subsection{Legislative Requirements for Energy-Efficiency Measure Selection}

The law requiring revision of the MHCSS energy-efficiency standards (HCDA 1987) and the accompanying conference report (CRH 1987) set requirements that affect the selection of the EEMs used in the 1992 analysis. Both the law and the congressional report were also treated as requirements in development of the revised requirements. The statutory requirements specify

- the perspective used to define the costs and benefits

- consideration of manufactured home design and factory construction techniques.

The standard was to be developed using "costs to the owner of a manufactured home" (CRH 1987). Therefore, all costs and benefits were calculated from the homeowner's perspective, with costs expressed at the retail (as opposed to wholesale) level.

The requirements to consider "factory construction techniques" (HCDA 1987) and "design ... of manufactured homes" (HCDA 1987) was interpreted to limit the EEMs to those commercially available as an option in a manufacturer's product line.

\subsection{Energy-Efficiency Measure Characteristics Required}

Energy-efficiency measure option characteristics must be determined for all manufactured home components. These components include ceilings, walls, floors, and windows. For each component, a list of EEM options and associated characteristics was produced, including EEM U-value, cost and lifetime. The calculation of U-values for each EEM is described in 1992 report (Conner et al. 1992, Appendix B). 


\subsection{Prototype Home}

This analysis used prototypical single- and double-wide homes. The dimensions chosen were the same as the 1992 analysis parameters and are shown in Table 3.1 in bold font. Initial results showed single- and double-wide homes produced very similar U-values. Since the average home size is increasing and double-wide homes dominate sales, the double-wide prototype was used for the analysis. Because the ratio of the areas determines the Uo, the actual areas are not as important as long as the ratios are reasonable.

Table 4.1 Prototypical Home Parameters

\begin{tabular}{|c|c|}
\hline Value & Source \\
\hline \multicolumn{2}{|r|}{ Length (ft) } \\
\hline 56 & Conner et al. 1992 \\
\hline 50 & NAHBRC 1998 \\
\hline 56 & Levy 1989 \\
\hline \multicolumn{2}{|r|}{ Width (ft) } \\
\hline 28 & Conner et al. 1992 \\
\hline 24 & Levy 1989 \\
\hline 28 & NAHBRC 1998 \\
\hline \multicolumn{2}{|r|}{ Height (ft) } \\
\hline 7.5 & Conner et al. 1992 \\
\hline 8 & NAHBRC 1998 \\
\hline \multicolumn{2}{|r|}{ Floor Area $\left(\mathrm{ft}^{2}\right)$} \\
\hline 1568 & Conner et al. 1992 \\
\hline 1400 & NAHBRC 1998 \\
\hline 1470 & MHI 2003a for $1980-2000$ \\
\hline 1,675 & MHI 2003a for 2001 \\
\hline 1334 & Levy 1989 \\
\hline \multirow[t]{2}{*}{1568} & NPPC \\
\hline & Eckman 2002 \\
\hline \multicolumn{2}{|c|}{ Window Area (\% of floor area) } \\
\hline 12 & Conner et al. 1992 \\
\hline 11 & Levy 1989 \\
\hline 19 & NPPC \\
\hline \multicolumn{2}{|r|}{ Door Area $\left(\mathrm{ft}^{2}\right)$} \\
\hline 36 & Conner et al. 1992 \\
\hline 36 & Levy 1989 \\
\hline 38 & NPPC \\
\hline
\end{tabular}




\subsection{Energy-Efficiency Measure Cost and Characteristics}

A set of EEM options was needed for the analysis. A cost was defined for each measure. The EEM U-values for ceilings, walls, and floor remain the same as in 1992 (Conner et al. 1992, Appendix B). HUD's $U_{0}$ is defined as the home's thermal shell and does not include infiltration or the required mechanical ventilation. Therefore, air leakage control and ventilation improvements, which may be very cost effective, were not included in the analysis.

\subsubsection{Energy-Efficiency Measure Cost Determination}

Because it was more available than manufactured home cost data, cost estimations were based partly on site-built cost data. According to the industry - "Depending on the region of the country, construction cost per square foot for a new manufactured home averages from 10 to $35 \%$ less than a comparable sitebuilt home." (MHI 2003) This implies lower EEM construction costs for manufactured homes. Therefore, overall costs reported here are likely biased towards the higher prices.

All costs reported here are the incremental costs for each EEM option above the price of the lowest level. For instance, for R-11, R-19, R-30 and R-38 ceilings, the additional cost above the R-11 was reported for the R-19, R-30 and R-38 ceilings.

\subsubsection{Ceiling Energy-Efficiency Measures}

Table 4.2 shows EEM options selected for the ceiling. Cost data is based on an assumed cost of $\$ 5$ per bag for cellulose with a manufacturer markup of 1.85 and a dealer markup of 1.34. ${ }^{\text {a }}$ The cost column in Table 4.2 is the cost per square feet above the base level of R-11.

Table 4.2. Ceiling EEM Options

\begin{tabular}{|c|c|c|}
\hline R-Value & Cost $\$ / \mathbf{f t}^{\mathbf{2}}$ & U-Value \\
\hline 11 & 0.00 & 0.091 \\
\hline 22 & 0.15 & 0.046 \\
\hline 33 & 0.32 & 0.033 \\
\hline 38 & 0.40 & 0.030 \\
\hline
\end{tabular}

\subsubsection{Wall Energy-Efficiency Measures}

The wall insulation cost data used in this analysis was a combination of the R.S. Means (2001) data and the California Database for Energy Efficient Resources (DEER) (Xenergy, Inc. 2001). Costs for

\footnotetext{
${ }^{\text {a }}$ Personal communication with Mike Lubliner, report co-author.
} 
changing from 2-by-4 to 2-by-6 framing to accommodate R-19 or R-21 insulation are included. The R.S. Means costs are $\$ 0.14 / \mathrm{ft}^{2}$ for the R-19 insulation instead of $\mathrm{R}-11$ and $\$ 0.37 / \mathrm{ft}^{2}$ for additional framing costs. The DEER provided incremental costs from regular-density (R-11 and R-19) to high-density batt insulation (R-13 and R-21). R.S. Means did not have this data. For this analysis, the DEER material costs were marked up by $20 \%$ to account for installation overhead and profit. Table 4.3 shows the resulting wall R-value costs.

Table 4.3. Wall EEM Option Characteristics

\begin{tabular}{|c|c|c|}
\hline R-Value & Cost $\$ \mathbf{f t}^{2}$ & U-Value \\
\hline 11 & 0.00 & 0.093 \\
\hline 13 & 0.07 & 0.083 \\
\hline 19 & 0.51 & 0.061 \\
\hline 21 & 0.86 & 0.055 \\
\hline
\end{tabular}

\subsubsection{Floor Energy-Efficiency Measures}

The approach used to estimate floor EEM costs was similar to that for the other component measures. Incremental levels of floor insulation are R-11, R-22, and R-33. Cost is based on an assumed cost of $\$ 0.012$ per R-1 of fiberglass insulation with a manufacturer markup of 1.85 and a dealer markup of 1.34 . Table 4.4 lists the EEM options, costs, and U-values for floor insulation.

Table 4.4. Floor EEM Option Characteristics.

\begin{tabular}{|c|c|c|}
\hline R-Value & Cost $\$ / \mathbf{f t}^{2}$ & U-Value \\
\hline 11 & 0.00 & 0.089 \\
\hline 22 & 0.33 & 0.041 \\
\hline 33 & 0.66 & 0.030 \\
\hline
\end{tabular}

\subsubsection{Window Energy-Efficiency Measures}

The most important aspect of assigning costs to windows is to correctly associate a cost and a Uvalue. Obtaining a cost-versus-energy-efficiency relationship is difficult for windows because window costs are greatly affected by non-energy characteristics such as appearance. The relatively rapid changes in window technology and energy efficiency also make obtaining window efficiency costs more difficult. Recent and continuing expansion in the use of vinyl framing and low-emissivity (low-E) coatings is driving a continuing trend towards lower price increments for more energy-efficient windows. 
The range of costs and efficiencies for the most cost-effective windows can be calculated using incremental prices for only a few energy-related features. The base window is a single-pane, aluminumframed window. The incremental changes involve going from a single to a double pane, going from aluminum to a vinyl (or wood) frame, adding a low-E coating, adding a window tint and adding argon gas. Costs for any given incremental thermal improvement were assumed to be constant regardless of other characteristics, for example, the costs of adding a low-E coating are the same for aluminum- and vinyl-frame windows.

The window cost data used in this analysis were taken primarily from the California Database for Energy Efficient Resources (DEER) (Xenergy 2001). This source had several advantages. First, DEER included costs for a fairly extensive set of window types from multiple manufacturers/suppliers. Second, the data include new energy-efficient technologies, such as vinyl framing, low-E surfaces, and argon gas. Third, these costs were recently updated. However, the cost increments for vinyl windows compared to aluminum windows from the DEER database was so low $\left(\$ 0.17 / \mathrm{ft}^{2}\right)$ that we chose to also consider older cost data. A higher cost premium of $\$ 1.61 / \mathrm{ft}^{2}$ was reported in the Manufactured Homes Acquisition Program in the Pacific Northwest (Ecotope 1995). The two vinyl price increments were averaged for this analysis. Low-E coatings were also a special case, as the price increment for low-E is falling fast. The cost for low-E coatings was estimated as $\$ 1 / \mathrm{ft}^{2}$.

U-values and solar heat gain coefficients (SHGC) for the types of windows are shown in Table 4.5 shows the window types used in the analysis. The U-values and SHGC are based on median values of windows from the National Fenestration Rating Council Certified Products Directory (1999). ${ }^{a}$ Low SHGC value is based on the value in the 2003 International Energy Conservation Code (IECC 2003), which creates a substantial demand in the south for glass with and SHGC of 0.40 or less; and therefore makes this glazing available and economical. Actual U-values and SHGC for available windows vary considerably.

Table 4.5. Window Types

\begin{tabular}{|c|c|c|c|}
\hline Window / Frame Type & Cost $\$ / \mathrm{ft}^{2}$ & U-Value & SHGC \\
\hline Single / aluminum & 0.00 & 1.20 & 0.79 \\
\hline Single / aluminum / tint & 1.86 & 1.20 & 0.40 \\
\hline Single / aluminum / storm & 2.40 & 0.80 & 0.65 \\
\hline Double / aluminum & 3.04 & 0.75 & 0.65 \\
\hline Double / aluminum / low-E & 4.04 & 0.59 & 0.40 \\
\hline Double / vinyl & 3.93 & 0.49 & 0.52 \\
\hline Double / vinyl / low-E & 4.93 & 0.35 & 0.40 \\
\hline
\end{tabular}

\footnotetext{
a The $\mathrm{U}$-value for low-E was adjusted from 0.36 to 0.35 , as this $\mathrm{U}$-value is expected to become a more common product due to building codes.
} 


\subsubsection{Crossover Duct}

A crossover duct with an area of $63 \mathrm{ft}^{2}$ and an R-value of 8 was assumed for the double-wide prototype.

\subsubsection{Door Energy-Efficiency Measures}

Two doors with a total area of $36 \mathrm{ft}^{2}$ and a U-value of 0.35 were assumed in the analysis. This Uvalue represents a reasonable door, the same door that is often required in the IECC. Doors down to 0.02 and lower are available. Doors have only a small effect on the $\mathrm{U}_{0}$ of a home.

\subsubsection{HVAC Equipment Energy-Efficiency Measures}

The National Appliance Energy Conservation Act of 1987 (NAECA) (Public Law 100-12) sets minimum efficiency standards that will apply to manufactured homes. Although the NAECA does not limit HUD's authority to require higher equipment efficiency (it does limit state and local authority), the NAECA does provide a single appliance efficiency standard for the United States. Because there was no clear mandate to require higher appliance efficiency levels in developing the 1992 standard, and this area is regulated by the NAECA, appliance efficiency was not examined in the current standard analysis. Instead, the NAECA minimum appliance efficiencies were assumed in the life-cycle cost calculation. For heat pumps and air conditioners, the minimum NAECA requirements that are expected to take effect in the year 2006 were assumed. The equipment efficiency levels used are shown in Table 4.6.

Table 4.6. Equipment Efficiencies

\begin{tabular}{|l|l|}
\hline \multicolumn{1}{|c|}{ System } & \multicolumn{1}{c|}{ Efficiency } \\
\hline Electric furnace & $100 \%$ \\
\hline Fossil fuel furnace & 75\% Annual Fuel Utilization Efficiency (AFUE) \\
\hline Heat pump & $\begin{array}{l}\text { 7.4 Heating Season Performance Factor (HSPF) with } \\
\text { 12 Seasonal Energy Efficiency Ratio (SEER) }\end{array}$ \\
\hline Air conditioner & 12 SEER \\
\hline
\end{tabular}

\subsubsection{Energy-Efficiency Measure Lifetime}

Insulation and windows were presumed to last the 30 -year lifetime assumed in the analysis, so there was no replacement cost. Equipment lifetimes were not needed for this analysis because the equipment efficiencies in the life-cycle cost analysis were fixed. 


\subsection{Least-Cost $\mathrm{U}_{\mathrm{o}} \mathrm{s}$ and $\mathrm{U}_{\mathrm{o}}$ Zones}

HUD requirements are specified as "maximum transmission heat loss coefficients in a number of climate zones" (CRH 1987). HUD requirements set $\mathrm{U}_{\mathrm{o}}$ maximums for the building envelope. The $\mathrm{U}_{\mathrm{o}}$ computation includes the contribution of each building component -- ceilings, walls, floors, windows, doors, and crossover ducts (for multi-section homes) -- with the U-value (U) of each component weighted by area (A), as shown below.

$\mathrm{U}_{\mathrm{o}}=(\mathrm{UxA})$ ceiling $+(\mathrm{UxA})$ wall $+(\mathrm{UxA})$ floor $+(\mathrm{UxA})$ window $+(\mathrm{UxA})$ door $+(\mathrm{UxA})$ crossover duct total exterior surface area

This chapter describes the creation of the Uo for the zones. This process started with ARES producing separate least-cost $\mathrm{U}_{\mathrm{o}} \mathrm{s}$ for each city and fuel/equipment type. 'These were aggregated in a series of steps to $\mathrm{U}_{\mathrm{o}} \mathrm{s}$ for each of the three zones in the existing HUD standard. The zones are shown in Figure 5.1.

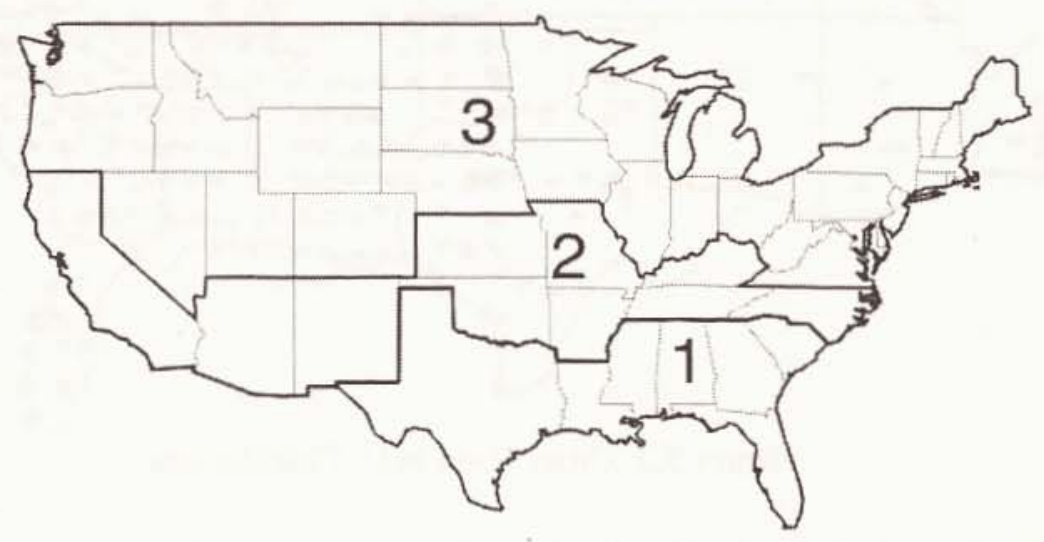

Figure 5.1 Existing $U_{0}$ Zones

\subsection{Individual Local Values}

Having defined the inputs to the least cost analysis (Chapters 3 and 4), the next step was calculation of EEMs for a large number of cites using ARES. For each city, five combinations of HVAC equipment and fuel were calculated:

- natural gas with a forced air furnace

- LPG with a forced air furnace

- oil with a forced air furnace

- electric resistance with a forced air furnace

- electric heat pump with forced air distribution.

All cases assumed electric air conditioning. 
All 881 cities available in ARES were used in the analysis. The cities for which calculations were performed are shown in Figure 5.2 and listed in the 1992 analysis (Conner et al. 1992, Appendix C). Selection of all 881 cities included in ARES provides a density of locations such that any point in the U.S. is not substantially separated from a location for which a least-cost $U_{0}$ was produced. The coverage of the U.S. with such a high density of points alleviates any bias that might have resulted from selecting a small number of cities to encompass a large area of the country. The selection of 881 cities, 5 equipment/fuel types resulted in the output of 4405 cases with specific $\mathrm{U}_{0} \mathrm{~s}^{\left({ }^{(a)}\right.}$

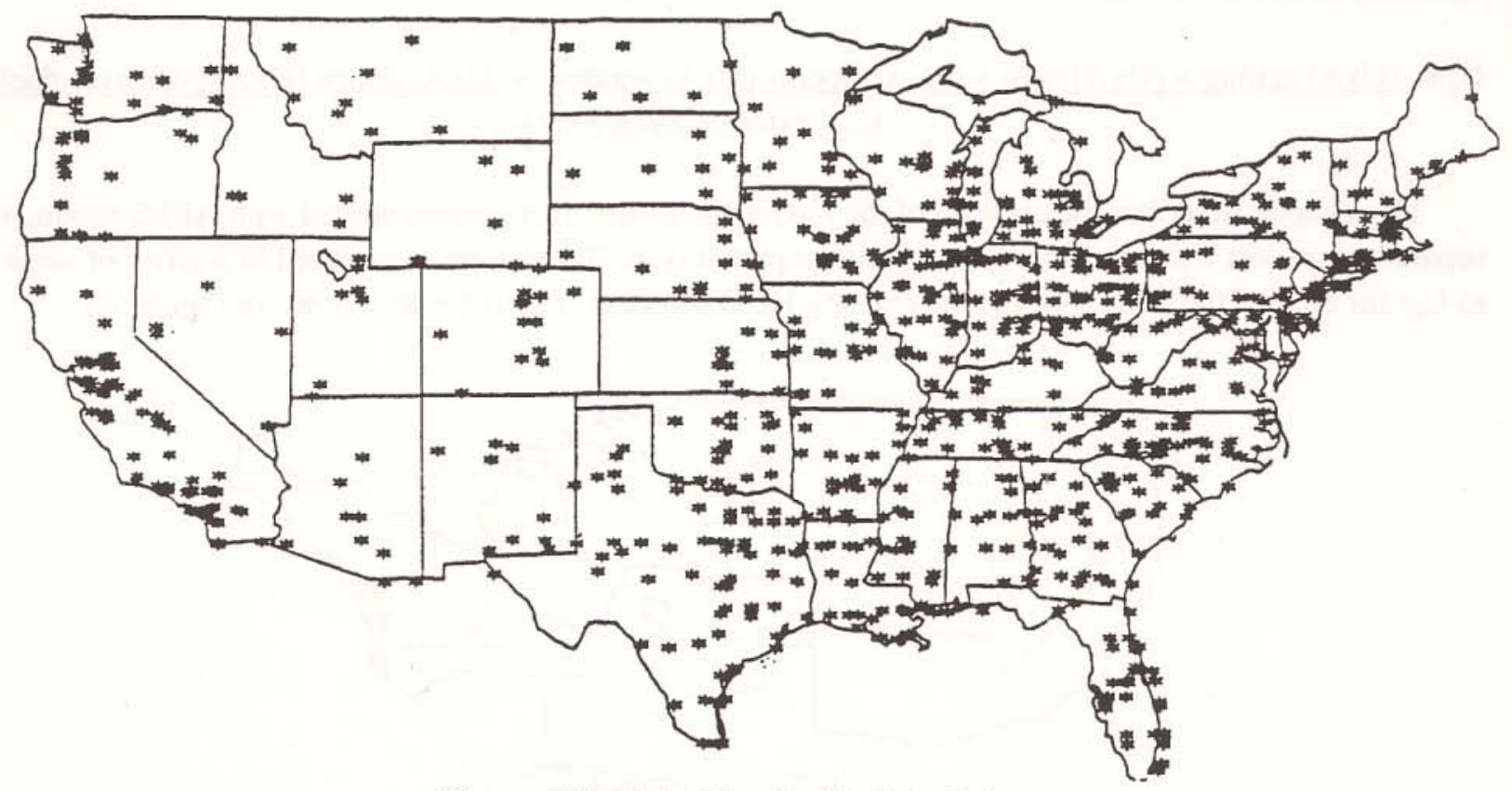

Figure 5.2. Cities Used in $U_{0}$ Calculations

The aggregation from the individual $U_{0} s$ to $U_{0} s$ for entire zones required several steps. ${ }^{b}$ The separate HVAC equipment and fuel type $\mathrm{U}_{\mathrm{o}} \mathrm{s}$ were aggregated into $\mathrm{U}$-values for all equipment/fuel types based on the prevalence of equipment types and fuels in each region.

City U-values were aggregated into state $\mathrm{U}_{0} \mathrm{~s}$. States were aggregated into zones based on shipments. As a practical matter, this analysis kept the existing HUD zones. To be competitive the industry needs large zones with uniform requirements.

a. To facilitate the production of the large number of least-cost $\mathrm{U}_{\mathrm{o}} \mathrm{s}$, software was created to run ARES in a "batch" mode.

b. All of the processing of the output of the ARES software was done with the statistical-graphics software called "S" (Backer and Chambers 1984). 


\subsection{Aggregation Across Equipment and Fuel Types}

The individual $\mathrm{U}_{\mathrm{o}} \mathrm{s}$ for each location and equipment/fuel type were aggregated into zones. For the existing zones, the aggregation was done based on state shipments. For the new zones, the aggregation was done based on residential building permit data.

A requirement with separate $\mathrm{U}$-values for each fuel/equipment type was considered. Two possibilities were considered: 1) producing separate electric and fossil fuel U-values (with heat pumps probably included in the fossil fuel U-values); and 2) producing a combined U-value that included all equipment/fuel types with the overall $U$-value weighted by the type of heating equipment present in each region.

Simplicity argues for a single $\mathrm{U}_{\mathrm{o}}$ for each zone. Separate fossil fuel and electric U-values would require manufacturers who built both types of homes to build all homes to the lower U-value or maintain two types of homes in inventory, one of which could only have fossil fuel furnaces. Having a single $U_{0}$ in each zone is also consistent with HUD's current standard and with most other $\mathrm{U}_{\mathrm{o}}$ based standards. Continuing to use a single $\mathrm{U}_{\mathrm{o}}$ for each zone is recommended here.

The $\mathrm{U}_{\mathrm{o}}$ for each location was the weighted average of the equipment and fuel types for the appropriate region. Fuel types by region obtained from the American Housing Survey (U.S. Census Bureau 2001) are shown in Table 5.1. (Values do not add to $100 \%$ because of other fuels, i.e. wood.) The zone $\mathrm{U}_{\mathrm{o}} \mathrm{s}$ were determined from the city U-values. Census data on 2002 building permits were used combines the cities within a state to produce a single state average $U_{\mathrm{o}}$ value (Census 2003). The weighting for each city is computed based $50 \%$ on the number of site-built permits (site-built is weighted towards urban/suburban areas) and $50 \%$ on distributing the homes equally by city (adds a factor to the distribution to account for the greater proportion of rural placements of manufactured homes).

Within a zone all the $\mathrm{U}_{\mathrm{o}} \mathrm{s}$ were aggregated together as a weighted average, with the weighting for each state being the state sales. The manufactured home shipment data by state for 2003 are shown in Appendix B.

Table 5.1. Fuel Types by Census Region (\%)

\begin{tabular}{|c|c|c|c|c|c|}
\hline Region & $\begin{array}{c}\text { Electric } \\
\text { Furnace }\end{array}$ & $\begin{array}{c}\text { Natural } \\
\text { Gas }\end{array}$ & $\begin{array}{c}\text { Heat } \\
\text { Pump }\end{array}$ & Oil & LPG \\
\hline Northeast & 12 & 19 & 0 & 37 & 28 \\
\hline Midwest & 19 & 42 & 2 & 2 & 32 \\
\hline South & 53 & 8 & 25 & 0 & 11 \\
\hline West & 38 & 40 & 10 & 0 & 9 \\
\hline
\end{tabular}




\section{$5.3 \mathrm{U}_{0}$ by Zone}

The existing and proposed $\mathrm{U}_{\mathrm{o}}$ requirements by zone are shown in Table 5.2.

Table $5.2 \mathrm{U}_{\mathrm{o}}$ by Zone

\begin{tabular}{|c|c|c|}
\hline Zone & Existing $\mathrm{U}_{\mathrm{o}}$ & Revised $\mathrm{U}_{\mathrm{o}}$ \\
\hline 1 & 0.116 & 0.086 \\
\hline 2 & 0.096 & 0.076 \\
\hline 3 & 0.079 & 0.064 \\
\hline
\end{tabular}

\subsection{Comparison to Existing Standard}

The proposed revised standard was compared to the existing 1992 MHCSS standard. As Table 5.2 shows, the revision proposed here is lower (more stringent) than the existing HUD standard.

Table 5.3. National Average $U_{0}$

$\begin{array}{ll}\frac{\text { Average } \mathrm{U}_{0}}{0.097} & \frac{\text { Standard }}{\text { Existing MHCSS standard }} \\ 0.075 & \text { Revision proposed in this report }\end{array}$

\subsection{Life-Cycle Savings, Mortgage Costs, and Energy Savings}

This section compares the costs and benefits from the consumers' perspective for the current HUD MHCSS and the proposed standards. The proposed standard always increases costs to buy the new EEMs and decreases costs for energy. The net present value from the consumer's perspective is the difference between the increased EEM costs and the decreased energy costs.

The additional cost per current practice home to meet the proposed standard would typically be in the range of $\$ 500$ to $\$ 700$. The first year savings in energy costs is $\$ 150$ to $\$ 180$ per year, producing a simple payback of less than five years in each of the three zones. Note that the monthly savings in energy costs exceeds the increase in monthly mortgage payment yielding an immediate positive cash flow in the first year for the consumer. The net life-cycle savings to the consumers ranges from $\$ 700$ to $\$ 1100$ per home. Simple paybacks are about 4.2 years, 4.0 years, and 3.3 years in zones 1, 2, and 3 respectively. 


\subsection{Typical R-values}

The standard prescribes only the overall maximum $\mathrm{U}_{\mathrm{o}}$, not the specific $\mathrm{R}$-values by component. Therefore there are a large number of potential combinations of insulation levels that meet those requirements. Table 4.4 illustrates a few possible combinations for a typical double-wide house. Other EEM combinations would also meet the standards. The R-values required for a specific home are dependent on the home design and construction and are particularly sensitive to the window area.

\begin{tabular}{|c|c|}
\hline Zone & \\
\hline 1 & $\begin{array}{l}\text { Existing } \mathrm{U}_{\mathrm{o}} \\
\text { Ceiling R-22, wall R-11, floor R-11, single-pane aluminum window with storm } \\
\text { Revised } \mathrm{U}_{\mathrm{o}} \\
\text { Ceiling R-22, wall R-11, floor R-22, double-pane aluminum window }\end{array}$ \\
\hline 2 & $\begin{array}{l}\text { Existing } \mathrm{U}_{\mathrm{o}} \\
\text { Ceiling R-22, wall R-11, floor R-22, single-pane aluminum window with storm } \\
\text { Revised } \mathrm{U}_{\mathrm{o}} \\
\text { Ceiling R-22, wall R-13, floor R-22, double-pane vinyl window }\end{array}$ \\
\hline 3 & $\begin{array}{l}\text { Existing } \mathrm{U}_{\mathrm{o}} \\
\text { Ceiling R-22, wall R-11, floor R-22, double-pane vinyl window } \\
\text { Revised } \mathrm{U}_{\mathrm{o}} \\
\text { Ceiling R-38, wall R-13, floor R-22, double-pane vinyl window with low-E }\end{array}$ \\
\hline
\end{tabular}

Table 5.4 Illustrative R-values by Zone 


\subsection{References}

American Homeownership and Economic Opportunity Act of 2000. 2000. Public Law 106-569. 114 Stat. 2944.

Backer, BA, and JM Chambers. 1984. S: An Interactive Environment for Data Analysis and Graphics. Bell Telephone Laboratories, Inc. Murray Hill, New Jersey.

Bankrate.com. 2003. Retrieved 7/13/03 from

http://www.bankrate.com/brm/news/mortgages/20020926a.asp?prodtype=mtg

Congressional Record - House (CRH), November 6, 1987, H9727.

Congressional Record - Senate (CRS), December 21, 1987, S18610.

Conner, CC, AD Lee, RG Lucas, and ZT Taylor. 1992. Revision of the Energy Conservation Requirements in the Manufactured Home Construction and Safety Standards. PNL-7109, Pacific Northwest National Laboratory, Richland Washington.

Conwell, VR. 1999. Financing a Manufactured Home. Retrieved 2/14/2002 from http://www.bankrate.com/brm/news/mtg/19990722.asp

Council of Economic Advisors. 2002. 2002 Economic Report of the President. United States Government Printing Office, Washington 2002. Retrieved 2/17/2003 from http://w3.access.gpo.gov/eop/

Eckman, T. 2002. 2002 Assumptions for calculations: Super Good Cents For Manufactured Housing. Northwest Power Planning Council. Portland, Oregon. Retrieved 7/11/2002 from http://www.nwcouncil.org/comments/downloaddetails.asp?s=2\&c=11\&sc=44, SGCMH.xls

Ecotope. 1995. Manufactured Home Acquisition Program, Analysis of Program Impacts. Seattle, Washington.

Foremost Insurance Group. 2002. The Market Facts. Grand Rapids, Missouri.

Foremost Insurance Group. 1988. Manufactured Homes: The Market Facts. Grand Rapids, Missouri.

Fuller, SK, AS Boyles. 2003. Energy Price Indices and Discount Factors for Life-Cycle Cost Analysis April 2003. National Institute for Science and Technology. NISTIR 85-3273-18. Gaithersburg, Maryland.

Gates, H. 1986. Occupied Life of Mobile Homes. Manufactured Housing Institute, Arlington, Virginia. Housing and Community Development Act (HCDA) of 1987. Public Law 100-242, Section 569. 
International Energy Conservation Code. 2003. International Code Council. Falls Church, Virginia.

Internal Revenue Service. 1999. Table 2.1-1999 Individual Income Tax Returns with Itemized

Deductions: Sources of Income, Adjustments, Itemized Deductions by Type, Exemptions and Tax Items by

Size of Adjusted Gross Income. Retrieved 2/24/2002 from http://www.irs.gov/pub/irs-soi/99in21id.xls

Levy, E. 1989. Development of Recommendations for Revision to the Manufactured Housing Construction and Safety Standards, Subpart F - Thermal Protection. The Levy Partnership, New York, New York.

Lortz, VB, and ZT Taylor. 1989. "Recommendations for Energy Conservation Standards for New Residential Buildings." Volume 2: Automated Residential Energy Standard- User's Guide - Version 1.1. PNL-6878, Vol. 2. Pacific Northwest National Laboratory, Richland, Washington.

Manufactured Housing Institute. 2000. Understanding Today's Manufactured Housing: The Fastest Growing Sector of the Home Building Industry. Manufactured Housing Institute, Arlington, Virginia.

Manufactured Housing Institute. 2002. Fast Facts . . Little Known Facts about Manufactured Housing. Retrieved 5/31/2002 from http://www.mfghome.org/fast facts.html

Manufactured Housing Institute. 2003a. Retrieved 7/7/2003 from http://www.manufacturedhousing.org/media_center/quick facts2003/cost_size.html

Manufactured Housing Institute. 2003b. Retrieved 7/13/2003 from http://www.manufacturedhousing.org/lib/showtemp detail.asp?id=336\&cat=5

Meeks, CB. 1998. Manufactured Home Life Existing Stock Through 1997. Manufactured Housing Institute.

NADA. 2003. Manufactured Housing Appraisal Guide Jan-April 2003. N.A.D.A. Official Used Car Guide Company, McLean, Virginia.

National Appliance Energy Conservation Act of 1987 (NAECA), Public Law 100-12.

National Association of Home Builders Research Center. 1998. Factory and Site-Built Housing: A Comparison for the $21^{\text {st }}$ Century. Prepared for U.S. Department of Housing and Urban Development.

National Association of Home Builders. 2001. Housing: Facts, Figures and Trends. National Association of Home Builders.

National Fenestration Rating Council. 1999 Certified Products Directory. Ninth edition. Silver Spring, Maryland. 
National Fire Protection Association. 2002. 2002 November Association Technical Meeting, Report on Proposals. National Fire Protection Association, Quincy MA.

National Fire Protection Association. 2003. NFPA 501 - Standard on Manufactured Housing, 2003

Edition. National Fire Protection Association, Quincy MA.

Northwest Power Planning Council (NPPC). Fourth Draft Northwest Conservation and Electric Power Plan, Appendix G. Retrieved 2/14/2002 from

http://www.nwcouncil.org/energy/powerplan/CRAC/backdocs.htm

Partnership for Advancing Technology in Housing (PATH). 1999. Innovations at the Cutting EdgeNew Ideas in Manufactured Housing. U.S. Department of Housing and Urban Development Office of Policy Development and Research, Washington, D.C.

Partnership for Advancing Technology in Housing (PATH). 2000. Home Builders' Guide to Manufactured Housing. U.S. Department of Housing and Urban Development Office of Policy Development and Research, Washington, D.C.

R.S. Means Company. (2001) Residential Cost Data $21^{\text {st }}$ Edition. Kingston, Massachusetts. www.rsmeans.com

U.S. Census Bureau, (2001) American Housing Survey Data. Retrieved 12/6/2002 from

http://www.census.gov/hhes/www/housing/ahs/ahs01/tab315.html

http://www.census.gov/prod/2002pubs/h150-01.pdf

U.S. Census Bureau, (2003) Building Permit Data.

http://www.census.gov/const/www/permitsindex.html

Xenergy. 2001 Database for Energy Efficient Resources Update Study: Final Report. Oakland, California. http://www.energy.ca.gov/deer/2001 DEER Update Study.PDF

24 CFR 3280. 1987. U.S. Department of Housing and Urban Development, "Manufactured Home Construction and Safety Standards." U.S. Code of Federal Regulations. 


\section{Appendix A}

Fuel Prices By State 


\section{Appendix A}

Table A.1. Fuel Prices by State

\begin{tabular}{|c|c|c|c|c|c|}
\hline \multirow[b]{2}{*}{ State } & \multicolumn{2}{|c|}{ Electricity } & \multirow{2}{*}{$\begin{array}{l}\text { Natural } \\
\text { Gas } \\
\text { \$/therm }\end{array}$} & \multirow[b]{2}{*}{$\begin{array}{l}\text { LP Gas } \\
\text { \$/gallon }\end{array}$} & \multirow[b]{2}{*}{$\begin{array}{c}\text { Oil } \\
\text { \$/gallon }\end{array}$} \\
\hline & $\begin{array}{l}\text { Winter } \\
\text { Cents }\end{array}$ & $\begin{array}{l}\text { Summer } \\
/ \mathrm{kWh}\end{array}$ & & & \\
\hline Alabama & 6.75 & 7.58 & 0.94 & 1.33 & 1.36 \\
\hline Alaska & 11.51 & 16.29 & 0.43 & 1.42 & 1.17 \\
\hline Arizona & 7.42 & 8.85 & 1.01 & 1.42 & 1.32 \\
\hline Arkansas & 6.70 & 7.91 & 0.53 & 1.33 & 1.36 \\
\hline California & 12.45 & 13.08 & 0.85 & 1.42 & 1.32 \\
\hline Colorado & 7.44 & 8.23 & 0.45 & 1.11 & 1.15 \\
\hline Connecticut & 10.54 & 11.73 & 1.15 & 1.46 & 1.34 \\
\hline Delaware & 7.81 & 9.46 & 0.92 & 1.48 & 1.43 \\
\hline DC & 7.42 & 9.52 & 1.18 & 1.48 & 1.44 \\
\hline Florida & 8.09 & 8.53 & 1.34 & 1.46 & 1.37 \\
\hline Georgia & 6.97 & 8.25 & 0.99 & 1.46 & 1.37 \\
\hline Hawaii & 16.35 & 16.41 & 2.24 & 1.42 & 1.32 \\
\hline Idaho & 6.58 & 6.13 & 0.67 & 1.11 & 1.12 \\
\hline Illinois & 7.49 & 9.16 & 0.71 & 1.04 & 1.16 \\
\hline Indiana & 6.51 & 7.14 & 0.82 & 1.04 & 1.22 \\
\hline lowa & 7.77 & 9.18 & 0.77 & 1.04 & 1.28 \\
\hline Kansas & 7.15 & 8.04 & 0.71 & 1.04 & 1.28 \\
\hline Kentucky & 5.39 & 6.07 & 0.79 & 1.04 & 1.28 \\
\hline Louisiana & 6.89 & 8.32 & 0.86 & 1.33 & 1.36 \\
\hline Maine & 12.94 & 12.88 & 1.16 & 1.46 & 1.30 \\
\hline Maryland & 6.73 & 8.96 & 0.93 & 1.48 & 1.44 \\
\hline Massachusetts & 10.70 & 11.90 & 1.12 & 1.46 & 1.38 \\
\hline Michigan & 8.35 & 8.79 & 0.61 & 1.04 & 1.26 \\
\hline Minnesota & 7.15 & 8.35 & 0.74 & 1.04 & 1.18 \\
\hline Mississippi & 6.95 & 7.97 & 0.82 & 1.33 & 1.36 \\
\hline Missouri & 6.04 & 8.02 & 0.78 & 1.04 & 1.28 \\
\hline Montana & 7.11 & 7.92 & 0.56 & 1.11 & 1.15 \\
\hline Nebraska & 5.90 & 7.85 & 0.65 & 1.04 & 1.28 \\
\hline Nevada & 9.52 & 8.62 & 0.83 & 1.42 & 1.32 \\
\hline New Hampshire & 11.72 & 12.14 & 0.98 & 1.46 & 1.30 \\
\hline New Jersey & 9.82 & 10.89 & 0.75 & 1.48 & 1.50 \\
\hline New Mexico & 8.39 & 8.94 & 0.68 & 1.33 & 1.36 \\
\hline New York & 12.92 & 14.97 & 0.95 & 1.48 & 1.42 \\
\hline North Carolina & 7.82 & 8.31 & 0.94 & 1.46 & 1.37 \\
\hline North Dakota & 5.92 & 7.47 & 0.6 & 1.04 & 1.28 \\
\hline Ohio & 7.44 & 9.02 & 0.79 & 1.04 & 1.22 \\
\hline Oklahoma & 6.35 & 8.27 & 0.7 & 1.04 & 1.28 \\
\hline Oregon & 6.99 & 7.24 & 0.93 & 1.42 & 1.29 \\
\hline
\end{tabular}




\begin{tabular}{|c|r|r|r|r|r|}
\hline State & \multicolumn{2}{|c|}{$\begin{array}{c}\text { Electricity } \\
\text { Winter } \\
\text { Cents/kWh }\end{array}$} & $\begin{array}{c}\text { Natural } \\
\text { Gas } \\
\text { \$/therm }\end{array}$ & $\begin{array}{c}\text { LP Gas } \\
\text { \$/gallon }\end{array}$ & $\begin{array}{c}\text { Oil } \\
\text { \$/gallon }\end{array}$ \\
\hline Pennsylvania & 9.02 & 10.25 & 0.94 & 1.48 & 1.31 \\
\hline Rhode Island & 10.51 & 11.98 & 1 & 1.46 & 1.35 \\
\hline South Carolina & 7.44 & 8.01 & 1.04 & 1.46 & 1.37 \\
\hline South Dakota & 7.00 & 8.22 & 0.73 & 1.04 & 1.28 \\
\hline Tennessee & 6.32 & 6.50 & 0.88 & 1.04 & 1.28 \\
\hline Texas & 7.94 & 9.74 & 0.75 & 1.33 & 1.36 \\
\hline Utah & 6.56 & 7.14 & 0.69 & 1.11 & 1.15 \\
\hline Vermont & 12.48 & 13.06 & 0.93 & 1.46 & 1.29 \\
\hline Virginia & 7.14 & 8.46 & 0.92 & 1.46 & 1.21 \\
\hline Washington & 6.19 & 6.31 & 0.75 & 1.42 & 1.41 \\
\hline West Virginia & 6.03 & 6.38 & 0.78 & 1.46 & 1.22 \\
\hline Wisconsin & 8.18 & 8.92 & 0.83 & 1.04 & 1.15 \\
\hline Wyoming & 6.65 & 7.47 & 0.54 & 1.11 & 1.15 \\
\hline
\end{tabular}

\section{References}

Energy Information Administration. 2002. Electric Power Monthly. U.S. Department of Energy, Washington, D.C. DOE/EIA-0226.

Energy Information Administration. 2002. Natural Gas Monthly. U.S. Department of Energy, Washington, D.C. DOE/EIA-0130.

Energy Information Administration. 2002. Petroleum Marketing Monthly. U.S. Department of Energy, Washington, D.C. DOE/EIA-0380. 
Appendix B

Home Shipments By State 


\section{Appendix B}

Table B.1. 2003 Home Shipments by State (thousands)

\begin{tabular}{|r|r|c|r|}
\hline State & Homes & State & Homes \\
\hline AL & 3210 & MT & 827 \\
\hline AK & 39 & NE & 354 \\
\hline AZ & 4454 & NV & 919 \\
\hline AR & 2347 & NH & 721 \\
\hline CA & 8441 & NJ & 731 \\
\hline CO & 1531 & NM & 1591 \\
\hline CT & 216 & NY & 2770 \\
\hline DE & 1190 & NC & 6996 \\
\hline FL & 10629 & ND & 297 \\
\hline GA & 4179 & OH & 3510 \\
\hline HI & 8 & OK & 2247 \\
\hline ID & 785 & OR & 2415 \\
\hline IL & 2265 & PA & 4057 \\
\hline IN & 3102 & RI & 44 \\
\hline IO & 682 & SC & 3779 \\
\hline KS & 828 & SD & 616 \\
\hline KY & 4635 & TN & 5187 \\
\hline LA & 4978 & TX & 10808 \\
\hline ME & 1115 & UT & 515 \\
\hline MD & 640 & VT & 328 \\
\hline MA & 294 & VA & 2975 \\
\hline MI & 4773 & WA & 2868 \\
\hline MN & 2248 & WV & 2159 \\
\hline MS & 2980 & WI & 2016 \\
\hline MO & 3500 & WY & 461 \\
\hline
\end{tabular}

\section{References}

Manufactured Housing Institute. 2003. Retrieved 7/9/2003 from

http://www.manufacturedhousing.org/media_center/quick_facts2003/econ_impacts.html

B-1 